\title{
Vascular endothelial growth factor increases messenger RNAs encoding cyclooxygenase-II and membrane-associated prostaglandin E synthase in rat luteal cells
}

\author{
T Sakurai, K Tamura and $\mathbf{H}$ Kogo \\ Department of Endocrine Pharmacology, Tokyo University of Pharmacy and Life Science, Hachioji, Horinouchi, 1432-1, Tokyo, 192-0392, Japan \\ (Requests for offprints should be addressed to K Tamura; Email: hiro@ps.toyaku.ac.jp)
}

\begin{abstract}
Vascular endothelial growth factor (VEGF) is known to be necessary for the vascularization of the developing corpus luteum. Our recent data suggested that cyclooxygenase-II (COX-II) may play a role in the formation of vascular plexuses in developing corpora lutea of the rat. Here we examined the relationship between VEGF and the expression of prostaglandin (PG)- metabolizing enzymes in rat ovarian luteal cells. VEGF treatment caused a dosedependent increase in the expression of COX-II and membrane-associated PGE synthase (mPGES) mRNA in cultured rat luteal cells. However, pretreatment of the luteal cells with a selective COX-II inhibitor, NS-398,
\end{abstract}

abolished the VEGF-enhanced mPGES mRNA expression. VEGF also increased $\mathrm{PGE}_{2}$ secretion. Conversely, $\mathrm{PGE}_{2}$ dose-dependently stimulated VEGF mRNA expression. Furthermore, VEGF induced VEGF mRNA expression, but this effect was abolished by NS-398 pretreatment. These findings suggest that VEGF enhances $\mathrm{PGE}_{2}$ production by stimulating COX-II and mPGES expression in rat corpus luteum and that the effect of VEGF on luteal cells may be partially mediated by this stimulation of $\mathrm{PGE}_{2}$ production.

Journal of Endocrinology (2004) 183, 527-533

\section{Introduction}

The corpus luteum is formed from the cellular components of the follicle after ovulation and it plays a critical role in the secretion of progesterone (P4), which maintains early pregnancy. Angiogenesis is dramatically induced in the corpus luteum as it grows and matures. During the establishment of pregnancy, the corpus luteum rapidly increases its size due to the augmented numbers of endothelial cells and increased luteal blood flow (Bruce et al. 1984). The acquirement of corpus luteum function is known to be dependent on the growth of new capillary vessels (Tamura \& Greenwald 1987, Smith et al. 1994, Ferrara et al. 1998, Reynolds et al. 2000) and it appears that this prominent vascularization of the corpus luteum may provide the luteal cells with the large amounts of cholesterol that are needed for $\mathrm{P} 4$ synthesis as well as aiding the delivery of $\mathrm{P} 4$ into the circulation.

Prostaglandins (PGs) are believed to modulate vascular permeability and angiogenesis (Ziche et al. 1982, Form \& Auerbach 1983). When the activity of cyclooxygenase (COX)-II - a rate-limiting enzyme for producing PGs - is inhibited, angiogenesis in colon cancer and tumor growth were suppressed (Tsujii et al. 1998). In addition, $\mathrm{PGE}_{2}$ reverses the inhibition of in vitro angiogenesis of rat aortic endothelial cells that is caused by the COX-II inhibitor NS-398 (Jones et al. 1999). We recently found that the activity of COX-II may be related to the formation of functional corpora lutea because it stimulates angiogenesis in immature rats (Sakurai et al. 2003). Briefly, we found that if gonadotropin-primed rats were injected with NS398 for 2 days after ovulation, serum P4 levels decreased, and this effect may be due to the NS-398-induced change in the vasculature of the developing corpus luteum. COX-II may be involved in the physiological angiogenesis of the corpus luteum that takes place during the early luteal phase in rats.

Vascular endothelial growth factor (VEGF) elicits angiogenesis by inducing endothelial proliferation, migration and tube formation, and plays a critical role in the regulation of vascular permeability and angiogenesis. This process involves the activation of multiple genes; candidate genes may be COX (Bryant et al. 1998, Gallo et al. 2001, Hernandez et al. 2001) and their products, eicosanoids (Tsujii et al. 1998, Amano et al. 2001). Furthermore, COX-II activity has been suggested to play a significant role in angiogenesis in carrageenin-induced granulation tissue (Ghosh et al. 2000) through its ability to stimulate VEGF production. Alternative splicing of the single VEGF gene results in several VEGF isoforms comprised of 121, 
145, 165, 189 and 206 amino acids $\left(\mathrm{VEGF}_{121}, \mathrm{VEGF}_{145}\right.$, $\mathrm{VEGF}_{165}, \mathrm{VEGF}_{189}$ and $\mathrm{VEGF}_{206}$ respectively) (Neufeld et al. 1999). $\mathrm{VEGF}_{165}$ and $\mathrm{VEGF}_{121}$ are secreted and act mitogenically on endothelial cells. VEGF is highly expressed in the luteinizing ovary (Ferrara et al. 1998). VEGF protein expression increases in luteinizing granulosa cells of the ovulatory follicle as well as in the developing corpus luteum in primates (Smith et al. 1994, Reynolds et al. 2000). Treatment in the preovulatory stage with an anti-VEGF receptor 2 antibody inhibits luteal angiogenesis in mice (Zimmermann et al. 2001). Thus, VEGF may be essential for the follicular angiogenesis that takes place during the early stage of luteinization in various species.

In the present study, we examined whether VEGF affects COX-II and membrane-associated prostaglandin E synthase (mPGES) mRNA expression in rat luteal cells. Moreover, we assessed whether $\mathrm{PGE}_{2}$ in turn influences VEGF mRNA expression.

\section{Materials and Methods}

\section{Luteal cell preparation and culture}

To obtain luteal cells, female rats were treated subcutaneously with $50 \mathrm{IU}$ equine chorionic gonadotropin (eCG; Teikoku Hormone MFG Co., Tokyo, Japan) and intraperitoneally with 25 IU human chorionic gonadotropin (hCG; Teikoku Hormone MFG Co.) at 23 and 25 days of age respectively; their ovaries were isolated on day 26 and digested with collagenase (Type I; Sigma) and DNase (Sigma). Highly purified luteal cells were collected from the collagenase-digested suspension by Percoll gradient centrifugation as described previously (Sakurai et al. 2003). The cells were then cultured at $1 \times 10^{6}$ cells $/ \mathrm{ml}$ in 12 -well plates for $24 \mathrm{~h}$ in Dulbecco's modified Eagle's medium (DMEM; Gibco) supplemented with 10\% fetal bovine serum (FBS), $100 \mu \mathrm{g} / \mathrm{ml}$ penicillin-streptomycin and $100 \mu \mathrm{g} / \mathrm{ml}$ gentamicin for $24 \mathrm{~h}$ at $37^{\circ} \mathrm{C}$ in a $95 \%$ air $-5 \%$ $\mathrm{CO}_{2}$ humidified environment. The cells were subsequently incubated for $24 \mathrm{~h}$ in serum-free DMEM and then treated for 6-30 h with $0 \cdot 1-30 \mathrm{ng} / \mathrm{ml}$ recombinant human VEGF $_{165}$ (R\&D Systems, Inc., Minneapolis, MN, USA). Alternatively, they were treated for $2 \mathrm{~h}$ with $0.003-3 \mu \mathrm{M} \mathrm{PGE}_{2}$ or with $10 \mu \mathrm{M}$ of the selective COX-II inhibitor NS-398 (Cayman Chemical, Ann Arbor, MI, USA). NS-398 was added $1 \mathrm{~h}$ before VEGF treatment. The culture media were collected for the P4 assay and the poly $(\mathrm{A})^{+}$RNAs of the cultured cells were isolated for Northern blotting. The P4 that was produced when the cells were exposed to $100 \mathrm{ng} / \mathrm{ml}$ ovine luteinizing hormone (LH) (NIDDK, oLH26 (AFP-5551B); obtained from Dr A F Parlow of the National Hormone and Pituitary Program, Harbor/UCLA Med Center, Torrance, CA, USA) was examined to confirm that the cells were steroidogenically responsive.

\section{RNA extraction and Northern blotting}

Poly $(\mathrm{A})^{+}$RNA was extracted from the cultured cells by using the QuickPrep micro mRNA Purification Kit (Amersham) according to the manufacturer's instructions and quantitated by absorbance at $260 \mathrm{~nm}$. To prepare the cRNA probes, partial cDNAs encoding rat $\mathrm{VEGF}_{164}$ / VEGF $_{188}$ (117 bp, 506-622; kindly provided by Dr M Shibuya, The Institute of Medical Science, University of Tokyo) and rat mPGES (710 bp, 1-709, kindly provided by Dr H Naraba, National Cardiovascular Center Research Institute, Osaka, Japan) were subcloned into the pCR II vector and the pGEM-T easy vector respectively. Moreover, partial cDNAs encoding rat COX-I (319 bp, 717-1036) and COX-II (212 bp, 945-1157) were subcloned into the pGEM-T easy vector. After linearization of each plasmid, the digoxygenin (DIG)-labeled antisense cRNA probes were synthesized by using an in vitro transcription kit (Toyobo, Tokyo) (Tamura et al. 1998). Northern blotting was performed using the DIG system as described previously (Tamura et al. 2003). Glyceraldehyde-3-phosphate dehydrogenase (G3PDH) expression was used as an internal control. The bands on the Kodak scientific imaging film (X-OMAT XB-1; Eastman Kodak) were analyzed by using NIH image (developed at the US National Institutes of Health and available on the Internet by anonymous FTP from zippy. nimh.nih.gov or on floppy disk from the National Technical Information Service, Springfield, Virginia, part number PB95-500195 GEI) and each value was normalized against that of the G3 PDH band in the corresponding lane.

\section{Measurement of $P G E_{2}$}

Cultured cells were treated with $10 \mathrm{ng} / \mathrm{ml} \mathrm{VEGF}$ in the presence or absence of $10 \mu \mathrm{M}$ NS-398 which was added $1 \mathrm{~h}$ before VEGF treatment. The cells were then incubated for $24 \mathrm{~h}$. The levels of $\mathrm{PGE}_{2}$ in the culture media were determined by using the Prostaglandin $\mathrm{E}_{2}$ Enzyme Immunoassay Kit (Assay Designs, Inc., Ann Arbor, MI, USA) according to the manufacturer's instructions.

\section{Statistical analysis}

The densitometry values and $\mathrm{PGE}_{2}$ levels in the culture media were measured. All experiments were repeated three times or more with triplicate wells in each experiment. All the densitometric analyses and the enzyme immunoassay data (the means of the values in each experiment) were used to obtain the mean \pm S.E.M. The statistical significance of the results was analyzed by applying Dunnett's test for multiple comparisons. A $P$ value of $<0.05$ was considered to be statistically significant. 

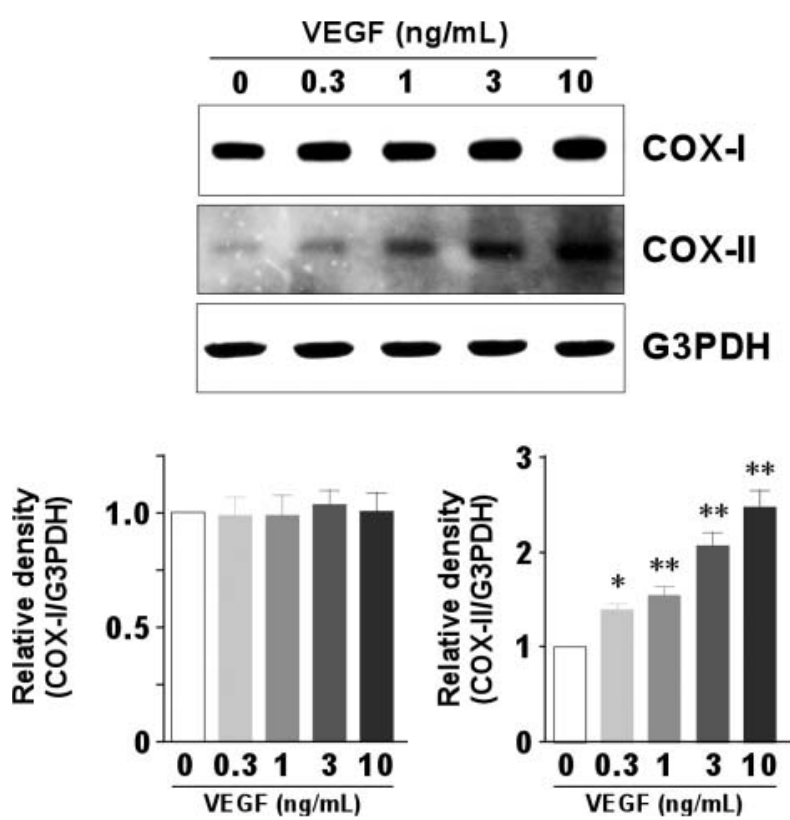

Figure 1 Effect of VEGF on COX-I and COX-II mRNA expression in cultured luteal cells. Luteal cells were collected from eCG-primed immature rats $24 \mathrm{~h}$ after hCG treatment and cultured for $6 \mathrm{~h}$ in the presence of various doses of VEGF $(0 \cdot 3-10 \mathrm{ng} / \mathrm{ml})$. Poly (A) ${ }^{+}$RNA $(0.5 \mu \mathrm{g}$ RNA) was then extracted for Northern blot analysis. Top panel, representative blots showing COX-I or COX-II mRNA expression. G3PDH mRNA was measured as a loading control. Bottom panel, the COX-I and COX-II mRNA levels in four independent experiments with triplicate wells, including the one shown in the top panel, were measured by densitometric analysis and the relative densities were determined by normalization against G3PDH mRNA levels. Statistical significance: ${ }^{*} P<0 \cdot 05$ and ${ }^{*} P<0 \cdot 01$ vs $0 \mathrm{ng} / \mathrm{ml}$ VEGF.

\section{Results}

Effect of VEGF on COX mRNA levels in cultured luteal cells

We determined whether treating cultured luteal cells with VEGF changes their expression of COX mRNA. As shown in Fig. 1, cultured luteal cells treated with 0.3$10 \mathrm{ng} / \mathrm{ml}$ VEGF showed a dose-dependent increase in their production of COX-II mRNA. In contrast, COX-I mRNA levels did not change. When we assessed the kinetics of the VEGF-induced enhancement of COX-II mRNA levels, we found that COX-II mRNA levels increased markedly within $6 \mathrm{~h}$ and that this level of stimulation was maintained for up to $12 \mathrm{~h}$ (data not shown). COX-II mRNA expression was also stimulated by treatment with $100 \mathrm{ng} / \mathrm{ml} \mathrm{LH}$ (data not shown).

\section{Effect of VEGF on mPGES mRNA levels in cultured luteal cells}

The effect of VEGF on the expression of mPGES mRNA in cultured luteal cells was also determined (Fig. 2). When
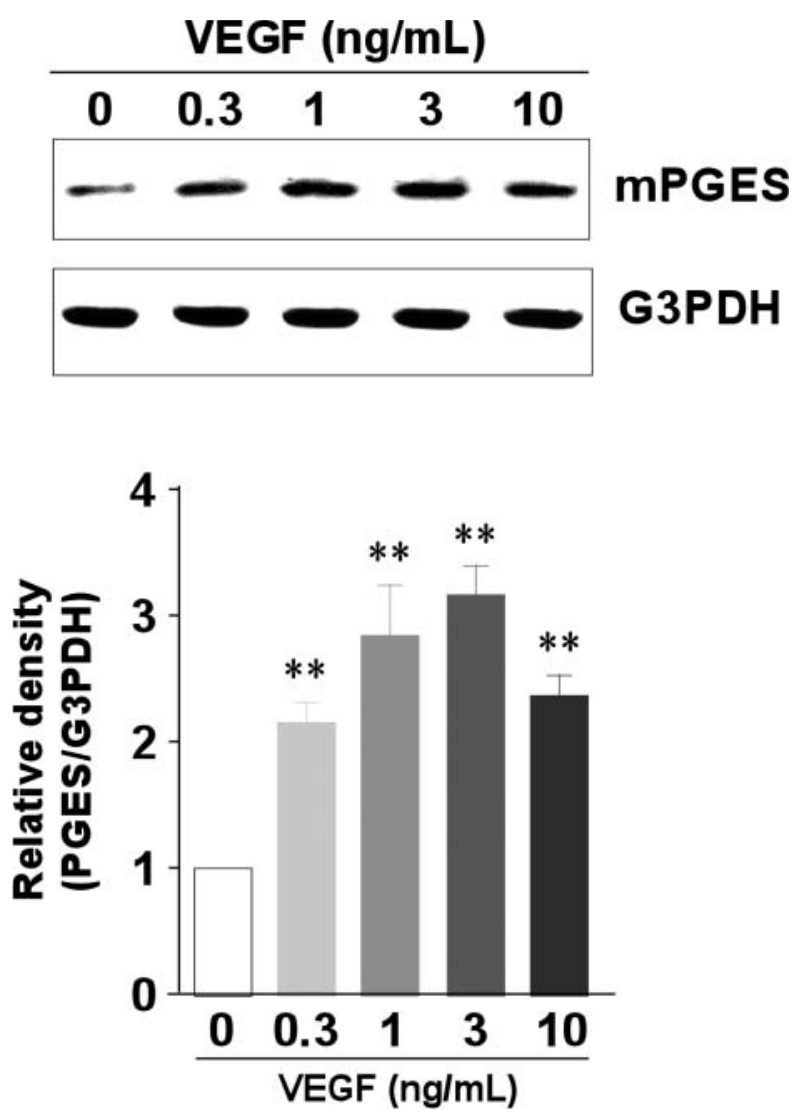

Figure 2 Effect of VEGF on mPGES mRNA expression in cultured luteal cells. Luteal cells were obtained and treated with VEGF as described in the legend to Fig. 1. A representative blot showing the mPGES mRNA expression in these cells is shown in the top panel. The mPGES mRNA levels in four independent experiments with triplicate wells, including the representative data in the upper panel, were analyzed by densitometry and the relative densities of the blots were determined by normalization against G3PDH mRNA levels. Statistical significance: ${ }^{* *} P<0 \cdot 01$ vs $0 \mathrm{ng} / \mathrm{ml}$ VEGF.

the luteal cells were treated with $0 \cdot 3-10 \mathrm{ng} / \mathrm{ml}$ VEGF, mPGES mRNA levels were enhanced. When the kinetics of the VEGF-enhanced expression of mPGES mRNA over the 6-24 h after VEGF treatment were examined, it was found that enhanced mPGES mRNA levels were seen within $6 \mathrm{~h}$ and that these peaked around $6 \mathrm{~h}$ (data not shown). We next examined the effect of preincubating the luteal cells with NS-398, a selective COX-II inhibitor, on the VEGF-induced mPGES mRNA levels (Fig. 3). Preincubation with $10 \mu \mathrm{M}$ NS-398 before VEGF $(10 \mathrm{ng} / \mathrm{ml})$ treatment abolished the VEGF-induced expression of mPGES mRNA.

Effect of VEGF on $P G E_{2}$ production by cultured luteal cells

The $\mathrm{PGE}_{2}$ concentrations in the culture media after the luteal cells were treated for $24 \mathrm{~h}$ with $10 \mathrm{ng} / \mathrm{ml}$ VEGF 


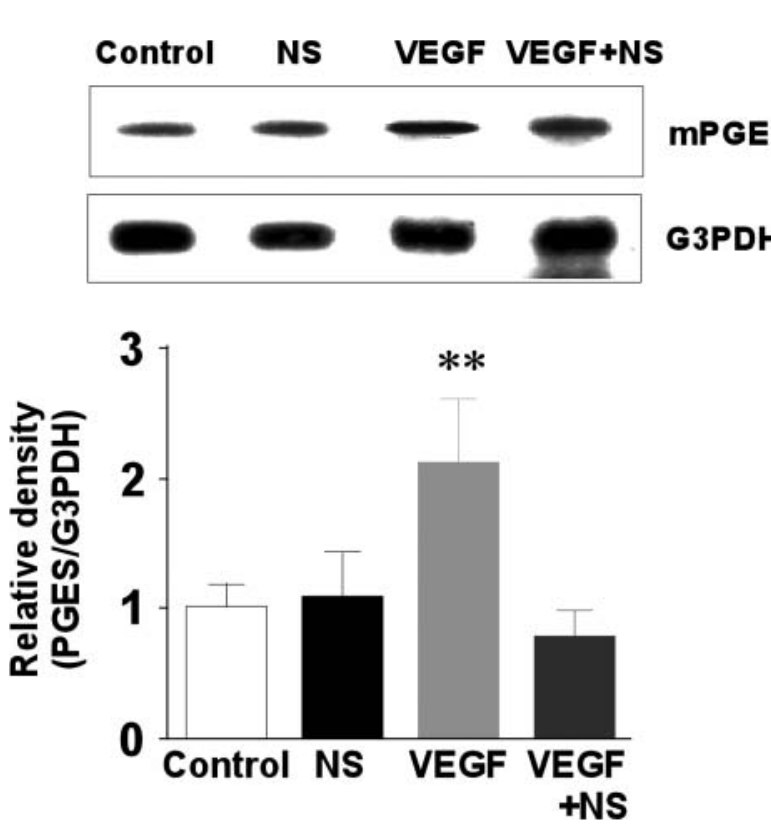

Figure 3 Effect of NS-398, a selective COX-II inhibitor, on VEGF-induced mPGES mRNA expression in cultured luteal cells. Luteal cells were treated with $10 \mathrm{ng} / \mathrm{ml}$ VEGF alone or with $10 \mu \mathrm{M}$ NS-398 (NS) for $6 \mathrm{~h}$. The inhibitor was added $1 \mathrm{~h}$ before VEGF was introduced. A representative blot showing mPGES mRNA levels is shown in the top panel. The mPGES mRNA levels in three independent experiments with triplicate wells, including the representative data in the upper panel, were analyzed by densitometry and the relative densities of the blots were determined by normalization against G3PDH mRNA levels. Statistical significance: ${ }^{* *} P<0 \cdot 01$ vs control.

and/or $10 \mu \mathrm{M}$ NS-398 are shown in Fig. 4. The $\mathrm{PGE}_{2}$ concentrations were approximately twofold higher in the VEGF-treated group compared with the control group. NS-398 treatment on its own tended to decrease the baseline $\mathrm{PGE}_{2}$ levels but this effect was not statistically significant. However, when the cells were first treated with NS-398 and then subjected to VEGF stimulation, the VEGF-induced production of $\mathrm{PGE}_{2}$ was significantly inhibited.

Effect of $P G E_{2}$ on VEGF $m R N A$ expression in cultured luteal cells

Figure 5 shows the effect of treating luteal cells with PGE2 on their expression of VEGF mRNA. The cells showed a dose-dependent increase in VEGF mRNA levels when they were treated with $0.003-3 \mu \mathrm{M} \mathrm{PGE}_{2}$ and then subjected to Northern blot analysis.

\section{Effect of VEGF on VEGF $m R N A$ expression in cultured luteal cells}

To explore a possible physiological mechanism by which VEGF induces luteal cells to produce $\mathrm{PGE}_{2}$ and through

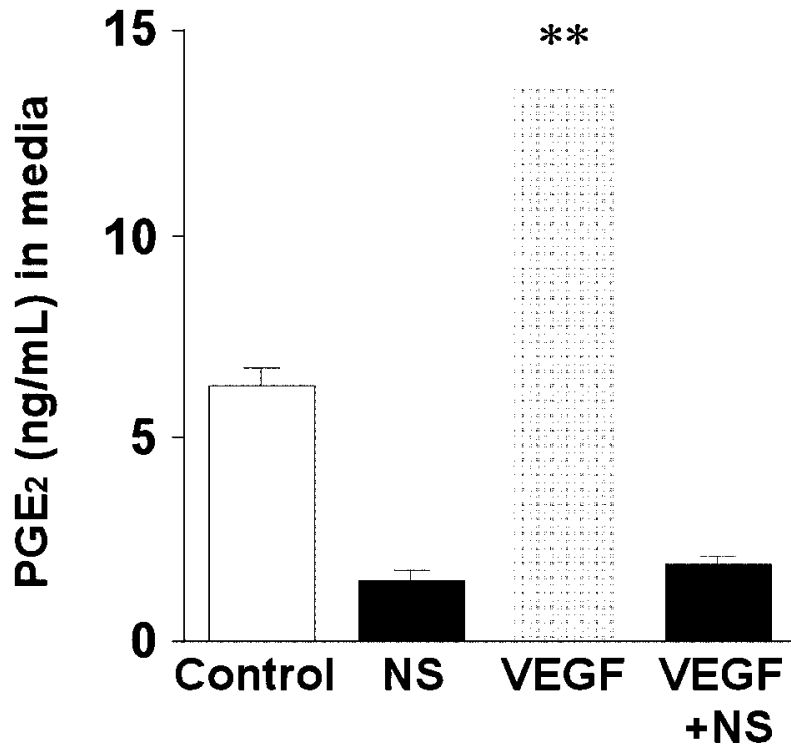

Figure 4 Effect of NS-398 on the VEGF-induced $\mathrm{PGE}_{2}$ production by luteal cells. Luteal cells were treated as described in the legend to Fig. 3 except that the incubation time was longer. Thus, cells were treated with $10 \mathrm{ng} / \mathrm{ml}$ VEGF alone or with $10 \mu \mathrm{M}$ NS-398 (NS) for $24 \mathrm{~h}$. The levels of $\mathrm{PGE}_{2}$ in the culture media were then evaluated by quantitative enzyme-linked immunosorbent assays. The results of four independent experiments are expressed as means \pm S.E.M. Statistical significance: ${ }^{* *} P<0.01$ vs control.

which $\mathrm{PGE}_{2}$ stimulates VEGF expression, the effect of VEGF on VEGF mRNA expression in cultured luteal cells was examined (Fig. 6). Thus, cells were cultured with $10 \mathrm{ng} / \mathrm{ml} \mathrm{VEGF}$ and/or $10 \mu \mathrm{M}$ NS-398 for $30 \mathrm{~h}$ and their VEGF mRNA levels were examined. VEGF treatment for $30 \mathrm{~h}$, but not for $6 \mathrm{~h}$ (data not shown), stimulated VEGF mRNA expression. However, pretreatment with NS-398 abolished the stimulatory effect of VEGF on VEGF mRNA expression.

\section{Discussion}

In the present study, we examined whether VEGF affects COX-II and mPGES mRNA expression in rat luteal cells and whether exposure of the cells to $\mathrm{PGE}_{2}$ influences their expression of VEGF mRNA. Our data indicated that VEGF stimulates the expression of COX-II and mPGES mRNA in luteal cells derived from early developing corpus luteum. VEGF also increased the production of $\mathrm{PGE}_{2}$ by these cells for $24 \mathrm{~h}$ after treatment. However, pretreatment of the cells with NS-398, a COX-II inhibitor, abolished the VEGF-induced $\mathrm{PGE}_{2}$ production. This observation is consistent with an earlier report using human endothelial cells (Tamura et al. 2002). NS-398 also suppresses the mPGES mRNA expression that is induced by VEGF. This observation indicates that the 

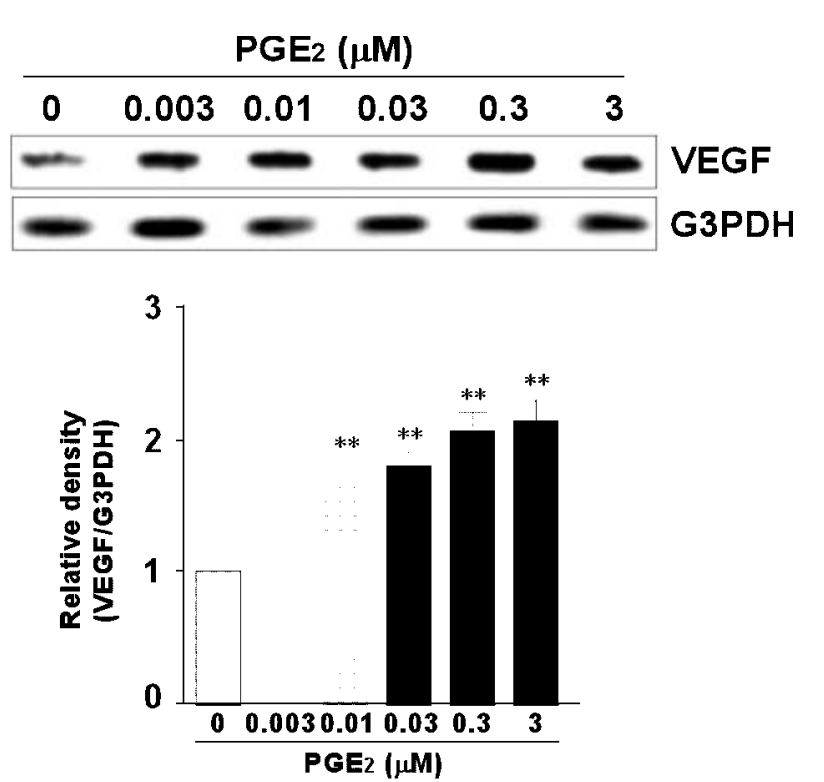

Figure 5 Effect of $\mathrm{PGE}_{2}$ on VEGF mRNA expression in cultured luteal cells. Luteal cells were incubated with 0.003-3 $\mu \mathrm{M} \mathrm{PGE}_{2}$ for $2 \mathrm{~h}$. A representative blot showing the VEGF mRNA levels is shown in the top panel. The VEGF mRNA levels in three independent experiments with triplicate wells, including the representative data in the upper panel, were analyzed by densitometry and the relative densities of the blots were determined by normalization against G3PDH mRNA levels. Statistical significance: ${ }^{*} P<0 \cdot 01$ vs $0 \mu \mathrm{M} \mathrm{PGE}_{2}$.

VEGF-induced mPGES mRNA expression requires COX-II activity in luteal cells. mPGES is an inducible enzyme that is highly expressed in the reproductive organs and is coordinately induced and functionally coupled with COX-II (Jakobsson et al. 1999, Murakami et al. 2000). The COX-II inhibitor reduces $\mathrm{PGE}_{2}$ generation in rat carrageenin-induced pleurisy more profoundly than other PGs (Harada et al. 1996). Ovarian follicular fluid after the ovulatory LH surge shows a distinct increase in $\mathrm{PGE}_{2}$ production (Brown \& Poyser 1984) and $\mathrm{PGE}_{2}$ treatment restores anovulation in COX-II-deficient mice (BenEzra 1978). Our present data suggest that the functional coupling of COX-II and mPGES may be important for the secretion of $\mathrm{PGE}_{2}$ by luteal cells, and that VEGF stimulates the expression of both molecules resulting in the production of a large amount of $\mathrm{PGE}_{2}$.

What could be the physiological role of the VEGFstimulated $\mathrm{PGE}_{2}$ production of luteal cells? Luteal $\mathrm{PGE}_{2}$ may directly promote the angiogenesis in the corpus luteum, which is usually induced during the early luteal phase, because it is known that $\mathrm{PGE}_{1}$ and $\mathrm{PGE}_{2}$ have a particularly enhanced pro-angiogenic effect (Ziche et al. 1982, Form \& Auerbach 1983). It has been reported that $\mathrm{PGE}_{2}$ participates in angiogenesis by several mechanisms (Peterson 1983, Leahy 2000, Salcedo et al. 2003). For example, Jones et al. (1999) indicated that the nonsteroidal anti-inflammatory drug (NSAID)-induced inhi-
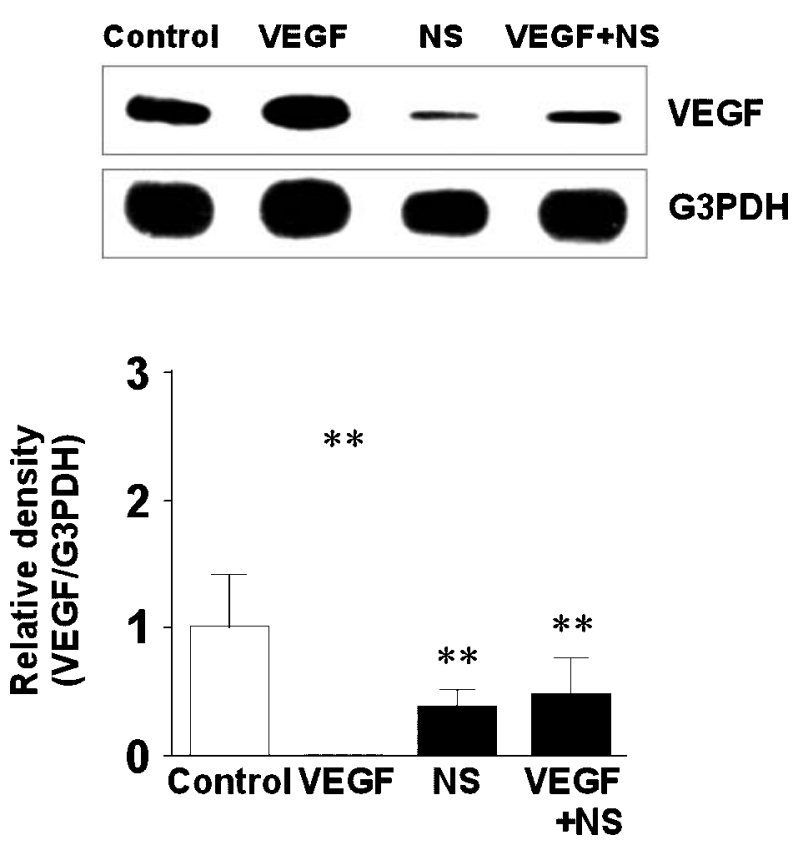

Figure 6 Effect of VEGF on VEGF mRNA expression and of NS-398 pretreatment on VEGF-enhanced VEGF mRNA levels in cultured luteal cells. The cells were treated as indicated in the legend to Fig. 3 except that the incubation time after VEGF treatment was $30 \mathrm{~h}$. The poly (A) ${ }^{+}$RNA $(0.5 \mu \mathrm{g}$ RNA) was then extracted from the cultured cells for Northern blot analysis. The relative densities were determined by normalization against the G3PDH mRNA levels (triplicate wells in each case). Statistical significance: ${ }^{* \star} P<0 \cdot 01$ vs control.

bition of the in vitro angiogenesis of human microvascular endothelial cells is partially reversed by the addition of $\mathrm{PGE}_{2}$. Addition of $\mathrm{PGE}_{2}$ to a luteal cell culture increased the levels of $\mathrm{P} 4$ in the culture media (data not shown). The results suggest that high levels of $\mathrm{PGE}_{2}$, which may be induced by gonadotropin or inflammatory cytokines in vivo, may directly stimulate the production of $\mathrm{P} 4$ by rat luteal cells. This observation is consistent with the reports of Horvath et al. (1986) and Elvin et al. (2000).

One particularly interesting finding in the present study was that $\mathrm{PGE}_{2}$ enhanced VEGF mRNA expression. Several mechanisms are involved in regulating VEGF gene expression in the ovary (Ravindranath et al. 1992, Neulen et al. 1995, Christenson \& Stouffer 1997, Pai et al. 2001). $\mathrm{PGE}_{2}$-elicited cAMP is known to be one of the mediators of VEGF expression (Lopez Bernal et al. 1995). We found that exogenous $\mathrm{PGE}_{2}(30 \mathrm{pM})$ significantly induced VEGF mRNA expression and that $\mathrm{PGE}_{2}$ concentration in the culture media $24 \mathrm{~h}$ after VEGF treatment approximated $30 \mathrm{pM}(12 \mathrm{ng} / \mathrm{ml})$, as shown in Fig. 4. There is a possibility that endogenous $\mathrm{PGE}_{2}$ may induce VEGF mRNA expression in luteal cells. Supporting our observations are reports that show a similar $\mathrm{PGE}_{2^{-}}$ mediated enhancement of VEGF expression in rat gastric microvascular endothelial cells (Pai et al. 2001) and human 


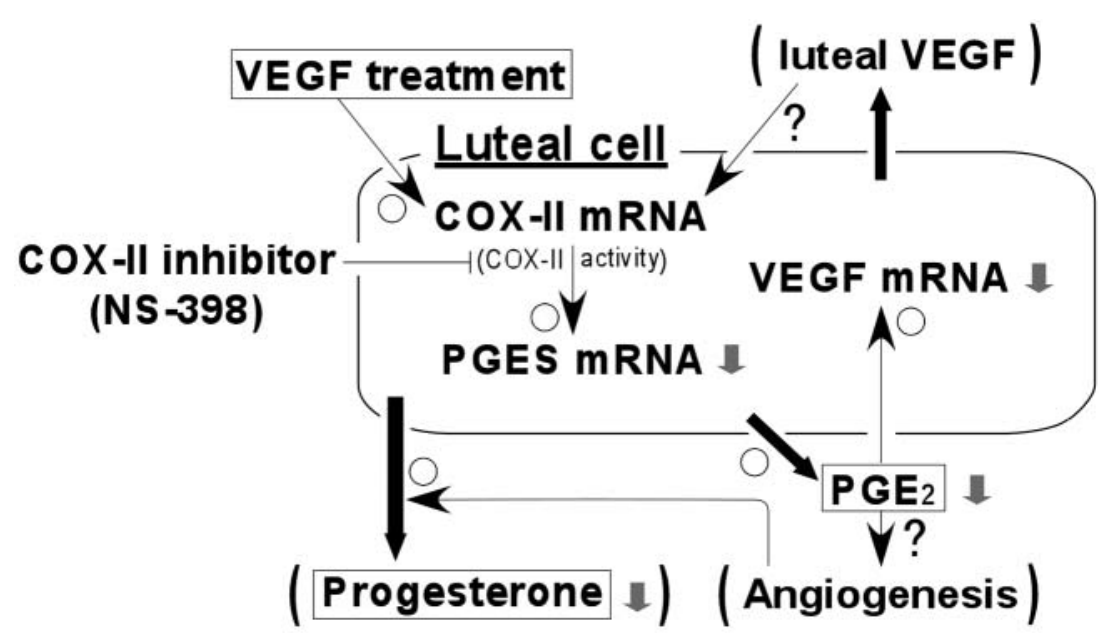

: Stimulation by VEGF treatment

$\longrightarrow$ : Secretion

\section{1 : Expression or secretion inhibited by the COX-II inhibitor}

Figure $7 \mathrm{~A}$ possible mechanism by which VEGF induces $\mathrm{PGE}_{2}$ secretion, and the roles of $\mathrm{PGE}_{2}$ in the functions of luteal cells during the early luteal phase in rats.

granulosa-luteal cells (Laitinen et al. 1997). The addition of NS-398 alone inhibits VEGF mRNA levels. The cause of this inhibition might be due to the abolishment of the stimulatory effects of endogenous $\mathrm{PGE}_{2}$ secreted from luteal cells. Taken together, our findings suggest that VEGF, COX-II, PGES and $\mathrm{PGE}_{2}$ may interact in luteal cells during the early stage of corpus luteum development in rats (Fig. 7). An increase in VEGF expression may induce COX-II and mPGES mRNA expression, which together stimulate $\mathrm{PGE}_{2}$ production. The increase in $\mathrm{PGE}_{2}$ levels might affect $\mathrm{P} 4$ production, possibly by enhancing angiogenesis in the corpus luteum, and further enhancing VEGF mRNA expression. Thus, there may be a positive feedback loop between VEGF expression and $\mathrm{PGE}_{2}$ production.

The present study shows that VEGF stimulates $\mathrm{PGE}_{2}$ production and VEGF mRNA expression in luteal cells but that this effect is abolished by NS-398 pretreatment. This demonstrates that ovarian COX-II activity is associated with enhanced VEGF expression, which is considered to be essential for angiogenesis in the corpus luteum. Both VEGF and $\mathrm{PGE}_{2}$ are produced at high levels around the time of ovulation and luteinization in the ovary. This autocrine feedback loop may contribute to the increases in the levels of these factors and thus may be associated with angiogenesis and blood vessel permeability that promotes the development of corpus luteum function.

\section{Funding}

This work was partially supported by a Grant-in-Aid for Scientific Research from the Promotion and Mutual Aid Corporation for Private Schools of Japan. The authors declare that there is no conflict of interest that would prejudice the impartiality of this scientific work.

\section{References}

Amano H, Ando K, Minamida S, Hayashi I, Ogino M, Yamashina S, Yoshimura H \& Majima M 2001 Adenylate cyclase/protein kinase A signaling pathway enhances angiogenesis through induction of vascular endothelial growth factor in vivo. Japanese Journal of Pharmacology 87 181-188.

BenEzra D 1978 Neovasculogenic ability of prostaglandins, growth factors, and synthetic chemoattractants. American Journal of Ophthalmology 86 455-461.

Brown CG \& Poyser NL 1984 Studies on ovarian prostaglandin production in relation to ovulation in the rat. Journal of Reproduction and Fertility 72 407-414.

Bruce NW, Meyer GT \& Dharmarajan AM 1984 Rate of blood flow and growth of the corpora lutea of pregnancy and of previous cycles throughout pregnancy in the rat. Journal of Reproduction and Fertility $71445-452$.

Bryant CE, Appleton I \& Mitchell JA 1998 Vascular endothelial growth factor upregulates constitutive cyclooxygenase 1 in primary bovine and human endothelial cells. Life Sciences $\mathbf{6 2}$ 2195-2201. 
Christenson LK \& Stouffer RL 1997 Follicle-stimulating hormone and luteinizing hormone/chorionic gonadotropin stimulation of vascular endothelial growth factor production by macaque granulosa cells from pre- and periovulatory follicles. Journal of Clinical Endocrinology and Metabolism 82 2135-2142.

Elvin JA, Yan C \& Matzuk MM 2000 Growth differentiation factor-9 stimulates progesterone synthesis in granulosa cells via a prostaglandin $\mathrm{E}_{2}$ /EP2 receptor pathway. PNAS 97 10288-10293.

Ferrara N, Chen H, Davis-Smyth T, Gerber HP, Nguyen TN, Peers D, Chisholm V, Hillan KJ \& Schwall RH 1998 Vascular endothelial growth factor is essential for corpus luteum angiogenesis. Nature Medicine 4 336-340.

Form DM \& Auerbach R $1983 \mathrm{PGE}_{2}$ and angiogenesis. Proceedings of the Society for Experimental Biology and Medicine 172 214-218.

Gallo O, Franchi A, Magnelli L, Sardi I, Vannacci A , Boddi V, Chiarugi V \& Masini E 2001 Cyclooxygenase-2 pathway correlates with VEGF expression in head and neck cancer. Implications for tumor angiogenesis and metastasis. Neoplasia 3 53-61.

Ghosh AK, Hirasawa N, Niki H \& Ohuchi K. 2000 Cyclooxygenase-2-mediated angiogenesis in carrageenin-induced granulation tissue in rats. Journal of Pharmacology and Experimental Therapeutics $295802-809$.

Harada Y, Hatanaka K, Kawamura M, Saito M, Ogino M, Majima M, Ohno T, Ogino K, Yamamoto K, Taketani Y, Yamamoto S \& Katori M 1996 Role of prostaglandin $\mathrm{H}$ synthase-2 in prostaglandin $\mathrm{E}_{2}$ formation in rat carrageenin-induced pleurisy. Prostaglandins $\mathbf{5 1}$ $19-33$.

Hernandez GL, Volpert OV, Iniguez MA , Lorenzo E, Martinez-Martinez S, Grau R, Fresno M \& Redondo JM 2001 Selective inhibition of vascular endothelial growth factor-mediated angiogenesis by cyclosporin $\mathrm{A}$ : roles of the nuclear factor of activated $\mathrm{T}$ cells and cyclooxygenase 2. Journal of Experimental Medicine 193 607-620.

Horvath E, Varga B \& Stark E 1986 Stimulation of progesterone production by adrenocorticotropic hormone and prostaglandin $\mathrm{E}_{2}$ in rat luteal cells. Biology of Reproduction 35 44-43.

Jakobsson PJ, Thoren S, Morgenstern R \& Samuelsson B 1999 Identification of human prostaglandin $\mathrm{E}$ synthase: a microsomal, glutathione-dependent, inducible enzyme, constituting a potential novel drug target. PNAS 96 7220-7225.

Jones MK, Wang H, Peskar BM, Levin E, Itani RM, Sarfeh IJ \& Tarnawski AS 1999 Inhibition of angiogenesis by nonsteroidal anti-inflammatory drugs: insight into mechanisms and implications for cancer growth and ulcer healing. Nature Medicine 5 1418-1423.

Laitinen M, Ristimaki A, Honkasalo M, Narko K, Paavonen K \& Ritvos O 1997 Differential hormonal regulation of vascular endothelial growth factors VEGF, VEGF-B, and VEGF-C messenger ribonucleic acid levels in cultured human granulosa-luteal cells. Endocrinology 138 4748-4756.

Leahy KM, Koki AT \& Masferrer JL 2000 Role of cyclooxygenases in angiogenesis. Current Medicinal Chemistry 7 1163-1170.

Lopez Bernal A, Bellinger J, Marshall JM, Phaneuf S, Europe-Finner GN, Asboth G \& Barlow DH 1995 G protein expression and second messenger formation in human granulosa cells. Journal of Reproduction and Fertility 104 77-83.

Murakami M, Naraba H, Tanioka T, Semmyo N, Nakatani Y, Kojima F, Ikeda T, Fueki M, Ueno A, Oh S \& Kudo I 2000 Regulation of prostaglandin $\mathrm{E}_{2}$ biosynthesis by inducible membrane-associated prostaglandin $\mathrm{E}_{2}$ synthase that acts in concert with cyclooxygenase-2. Journal of Biological Chemistry 275 32783-32792.

Neufeld G, Cohen T, Gengrinovitch S \& Poltorak Z 1999 Vascular endothelial growth factor (VEGF) and its receptors. FASEB Journal 13 9-22.
Neulen J, Yan Z, Raczek S, Weindel K, Keck C, Weich HAi, Marme D \& Breckwoldt M 1995 Human chorionic gonadotropin-dependent expression of vascular endothelial growth factor/vascular permeability factor in human granulosa cells: importance in ovarian hyperstimulation syndrome. Journal of Clinical Endocrinology and Metabolism 80 1967-1971.

Pai R, Szabo IL, Soreghan BA, Atay S, Kawanaka H \& Tarnawski AS $2001 \mathrm{PGE}_{2}$ stimulates VEGF expression in endothelial cells via ERK2/JNK1 signaling pathways. Biochemical and Biophysical Research Communications 286 923-928.

Peterson HI 1983 Effects of prostaglandin synthesis inhibitors on tumor growth and vascularization. Experimental studies in the rat. Invasion and Metastasis 3 151-159.

Ravindranath N, Little-Ihrig L, Phillips HS, Ferrara N \& Zeleznik AJ 1992 Vascular endothelial growth factor messenger ribonucleic acid expression in the primate ovary. Endocrinology 131 254-260.

Reynolds LP, Grazul-Bilska AT \& Redmer DA 2000 Angiogenesis in the corpus luteum. Endocrine 12 1-9.

Sakurai T, Tamura K, Okamoto S, Hara T \& Kogo H 2003 Possible role of cyclooxygenase-II in the acquisition of ovarian luteal function in rodents. Biology of Reproduction 69 835-842.

Salcedo R, Zhang X, Young HA, Michael N, Wasserman K, Ma WH, Martins-Green M, Murphy WJ \& Oppenheim JJ 2003 Angiogenic effects of prostaglandin $\mathrm{E}_{2}$ are mediated by up-regulation of CXCR4 on human microvascular endothelial cells. Blood 102 1966-1977.

Smith MF, McIntush EW \& Smith GW 1994 Mechanisms associated with corpus luteum development. Journal of Animal Science $\mathbf{7 2}$ $1857-1872$.

Tamura H \& Greenwald GS 1987 Angiogenesis and its hormonal control in the corpus luteum of the pregnant rat. Biology of Reproduction 36 1149-1154.

Tamura K, Tamura H, Kumasaka K, Miyajima A, Suga T \& Kogo H 1998 Ovarian immune cells express granulocyte-macrophage colony-stimulating factor (GM-CSF) during follicular growth and luteinization in gonadotropin-primed immature rodents. Molecular and Cellular Endocrinology 142 153-163.

Tamura K, Hara T, Yoshie M, Irie S, Sobel A \& Kogo H 2003 Enhanced expression of uterine stathmin during the process of implantation and decidualization in rats. Endocrinology 144 1464-1473.

Tamura M, Sebastian S, Gurates B, Yang S, Fang Z \& Bulun SE 2002 Vascular endothelial growth factor up-regulates cyclooxygenase-2 expression in human endothelial cells. Journal of Clinical Endocrinology and Metabolism 87 3504-3507.

Tsujii M, Kawano S, Tsuji S, Sawaoka H, Hori M \& DuBois RN 1998 Cyclooxygenase regulates angiogenesis induced by colon cancer cells. Cell 93 705-716.

Ziche M, Jones J \& Gullino PM 1982 Role of prostaglandin $\mathrm{E}_{1}$ and copper in angiogenesis. Journal of the National Cancer Institute 69 $475-482$.

Zimmermann RC, Hartman T, Bohlen P, Sauer MV \& Kitajewski J 2001 Preovulatory treatment of mice with anti-VEGF receptor 2 antibody inhibits angiogenesis in corpora lutea. Microvascular Research 62 15-25.

Received 25 June 2004

Accepted 24 August 2004

Made available online as an

Accepted Preprint 6 September 2004 